\title{
OBITUARY
}

\section{THOMAS DOUGLAS (DOUGAL) VICTOR SWINSCOW}

\section{July 1917-24 September 1992}

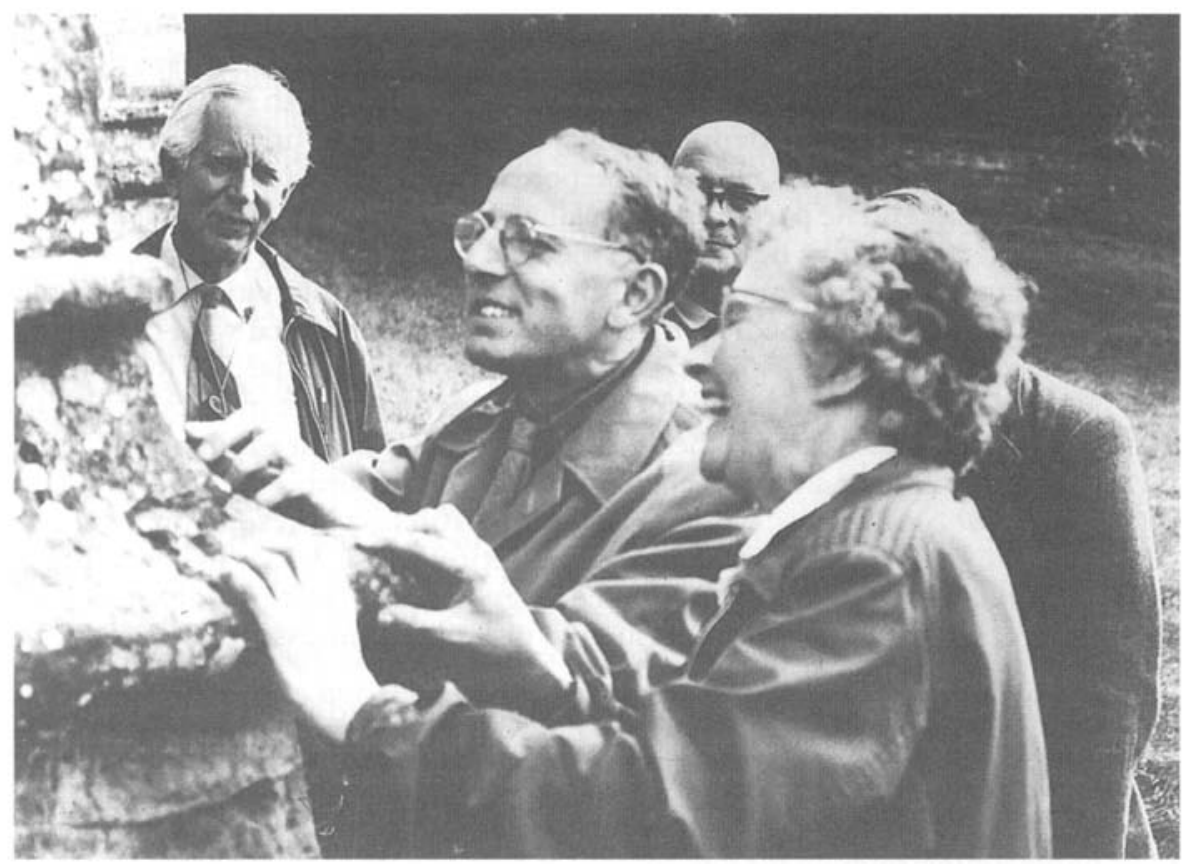

When interest and research in a particular group of plants appears to be at its lowest ebb, a renaissance in the subject can often be attributed to the initiative, foresight and leadership provided by a single individual who, by their charisma, energy and originality is able to rekindle a new enthusiasm for the group and set the subject on course for a future surge of scientific advancement. Undoubtedly, a person in this category was Dougal Swinscow, who was not only the major instigator of the revival of British lichenology from 1958 onwards but subsequently gave scholarly impetus to the study of tropical macrolichens.

Dougal's lifelong interest in natural history, a source of his quest for peace and tranquillity based on Taoist principles, probably derived from his 
emotionally turbulent upbringing, which he described in a highly entertaining autobiography published in 1989. An omnipresent mother, who, amongst her considerable eccentricities, was a crack pistol shot, a heavy pipe smoker, and consulted fortune tellers, and a remote self-effacing father caused him, in his teens, to find escape in the Devon lanes where he indulged his aptitude for natural history. There is no doubt, too, that this juxtaposition of parental opposites was instrumental in honing his ordered and positive approach to life, his academic resolve, his strong will, and made him a formidable, well-informed protagonist in discussions.

He had a distinguished army career, first on active service in the front line in the RAMC in N. Africa and later with the 1st Armoured Division at Arnhem, Holland, where he gained the Dutch equivalent to the DSO for courage and bravery in action. After the war, a brief flirtation with psychoanalysis as a career was put aside and in 1946 Dougal joined the staff of the British Medical Journal (BMJ) of which he became deputy editor, a post ably held until his retirement in 1977. He carried out his editorial responsibilities with consummate ability and personal flair and he particularly recalled with some relish the BMA's work in the turbulent meetings between the medical profession and the government in the setting up of the National Health Service. His pragmatic and sensible counsel on editorial and medical matters for the BMJ coupled with his extensive knowledge, often at instant recall, ensured a high standard of journalism and many pithy editorials aimed specifically at getting basic medical ethics to general practitioners. He was a persistent advocate of the need to reduce complexity and jargon to its simplest elements, an ambition amply demonstrated by his Statistics at Square One, which became, and still is, a best seller in the field. Rejecting the BMJ editorship he took semi-retirement in order to concentrate on his extracurricular interests-lichenology, natural history, gardens and their design, and Taoism. He continued to be a part-time associate on satellite journals of the BMJ until 1981.

Dougal's specific botanical studies were concentrated initially on pteridophytes and then on bryophytes. He became an active and contributory member of the two major relevant British societies devoted to these plants. He also became an expert in myxomycetes, which he used to cultivate in petri dishes on their natural substrates on his window sill at home or office from slimes found in the field. He benefited greatly from the ' expert tutelage' of Francis Rose, who above all taught him the importance of studying plants in their natural habitats and inculcated in him the 'feel' for a habitat and its identifying communities rather than just studying individual species in isolation. His visits to Ursula Duncan further advanced his knowledge of the Scottish Highlands and gave him his first introduction to lichens. He was impressed by her dedication and enthusiasm and particularly her success in 'spreading the gospel' to all her interested amateurs and 'beginners'. She introduced Dougal to lichens and through her the first inklings for the spectacular revival of British lichenology were set in motion during their visits to the Scottish mountains and glens.

By 1957 Dougal was becoming restive at the lack of what he conceived as a broadly based academic challenge within the bryophytes; his studies on Sphagnum filled this need for a while but were not sufficient to staunch his intellectual energies. He subsequently confessed to me at one of our weekly 
lunchtime meetings that he had deliberately explored the possibilities of a broader pioneering role in a neglected group of plants. His first thoughts turned to the myxomycetes, but his eventual choice was to be lichens. Little could he have imagined the impact and significance of his thoughts while walking through Borrowdale in the Lake District in the autumn of 1957 when he conceived the idea of forming a lichen society. His success is all the more remarkable considering the dearth of interest and lack of expertise at this time. He was, rightly so, immensely proud of the British Lichen Society formed in 1958. He played a most important role in getting it established, by formulating its rules, leading its early field meeting to Devon and, above all, establishing the publication of The Lichenologist. The first two issues were typed, after hours, by his secretary and produced by photolithography, appearing in November 1958 and March 1959. Thereafter the publication was printed by Fisher Knight and Co., the then printers of the BMJ. Throughout, he was adamant that the society membership should be international and that The Lichenologist should reflect that status. This, he believed would ensure its continuing strength and defend it from the insularity that plagued several societies, 'some now defunct ', at that time. His own concession to the origin of his creation was the retention of the word 'British' in the Society's title.

Those early days of the Society's activites were particularly exciting and adventurous and allowed Dougal to indulge more fully in an aspect he was to enjoy throughout his life, that of field work. In spite of a somewhat misleadingly frail appearance he was capable of more than the necessary energy and enthusiasm that are the hallmarks of good collectors. Our trips to Ireland and western Scotland, for a period in a Jaguar car, yielded a treasure trove of discoveries. Species with single localities in A. L. Smith's volumes were found to be key elements in a then unexpectedly rich and oceanic flora, which was to make the western side of the British Isles the prime site for oceanic lichens in Europe.

Although Dougal rapidly gained proficiency in understanding British macrolichens it was entirely characteristic of him that he should soon seek a greater challenge than the group had to offer. Thus he elected to work on British pyrenocarp lichens, a group that at the time was poorly understood and in many areas in a state of taxonomic confusion. Furthermore, nowhere was the broad divergence between British concepts of the genera and species from the rest of Europe so manifest. His pioneering and detailed research in this area resulted in an important series of papers in The Lichenologist between 1958 and 1971 , adding many new records to the British flora and critically revising several genera. He was awarded a Master of Science degree by London University in 1962 for his studies on Porina. These initial studies were to train and set the seal for his future work-a characteristically thorough analytical and methodical approach, a good working knowledge and understanding of the importance of 'The Code' and above all, a clarity of expression and writing that made the accuracy of his manuscripts an editor's dream. My own favourite memories of this period were our weekly lunches in South Kensington or Holborn where we would discuss anything from the politics of the day (on which we often differed), music-Bach cantatas, Mozart operas, and period performances on contemporary instruments (on which we often concurred), the latest novel, medical ethics, the latest lichenological discoveries and news, (the restaurant 
table often covered with specimens and relevant papers). Also, there were many happy evenings at his home in Knebworth after a long but fruitful day in the field, a select alcoholic libation at the elbow, cutting sections of perithecia, held in glitterwax (his discovery) with a freezing microtome to prepare slides for identification and comparison, many later to be the basis of illustrations for his papers. These 15 years saw a gradual emphasis on aquatic and marine pyrenocarps and many a robust epithet remained unheard as select specimens chipped from smooth rocks in streams were lost to a watery grave, never to be retrieved.

After his period of intensive study on British lichens, Dougal made an unexpected but, as it turned out, perceptive decision to alter his area of interest in lichens. He chose to embark on a marathon study of the macrolichen flora of East Africa. His fascination and love for the African continent and its people developed from a visit to South Africa in 1969 at the behest of the BMA, with a subsequent sight-seeing and botanical expedition to Uganda with the Norwegian botanist, Kåre Lye. However, such a monumental undertaking, one where collections were inadequate and the previous taxonomy unreliable, needed a collaborator and Dougal was very fortunate in interesting $\mathrm{Dr}$ (now Prof.) Hildur Krog of Oslo in joining forces with him. Thus one of the most successful duos in modern cryptogramic botany was established. Over more than 15 years new collections were amassed during well-planned expeditions often made under the turbulent and difficult circumstances of the post-colonial changes in the region at that time. Concurrently 33 papers were published jointly, including substantial and important revisions of genera and difficult species complexes, and many new species were described. During the process of compilation of their publications, Dougal as in other respects, often held wellfounded opinions that he would, on occasions, vigorously defend. Thus the final manuscripts would be a distillation of discussion by letter or phone or noisy but amicable set-tos with his co-author, much enjoyed by this eavesdropper during their welcome visits to the Museum. The culmination of this pioneering study The Macrolichens of East Africa appeared in 1988. A model of its kind and essential reading to all students of tropical lichenology this book is destined to become a classic as was perhaps foreseen by Dougal in a letter to his friend Stephen Lock, towards the end of his life and when he was seriously ill. 'All flags will be flying when I go down because I am conscious of having lived a full life and produced at least one work, on East African lichens, by which I shall be remembered into the next century ... Also I've been very lucky in having a very happy home life [Josephine and I] celebrate our golden wedding in a few days.'

After the publication of this magnum opus on lichens Dougal largely retired from active lichenology although he continued to maintain a keen interest in the British Lichen Society. His later years were given over to developing his concepts of mystic philosophy, which had derived from an experience of the communion of mankind with nature when he was 22 . This aspect of his thinking was latterly explored by him in depth as he became an accredited expert in gardens and garden design. His thoughts culminated in his last book, The Mystic Garden, in which he reflects on his lifelong concern for both the quality and debasement of the values and standards in life as well as exploring man's reliance on the ethics and aesthetics of life. With his wife, three daughters and their grandchildren, his poetry, music and pots (he was an expert on Devon 
ware) he perhaps came to terms with his earlier personal analysis of himself: 'more than most people I have a deeply felt need to reach a final harmonious chord'.

Always defending his amateur status resolutely, Dougal belonged to a declining group of individuals unique to British natural history who have enriched their subject immeasurably their friendships, philanthropy, worldly wisdom and quality of their scholarship. His publications and, above all, his founding of the British Lichen Society ensure that his impact on lichenology and lichenologists will not diminish or be forgotten.

\section{Publications}

Books

Swinscow, T. D. V. (1976) Statistics at Square One London: British Medical Association. Many editions and reprints. Dutch edition 1981. Japanese edition 1982. Edition as talking book for the blind.

Swinscow, T. D. V. \& Krog, H. (1988) Macrolichens of East Africa. London: British Museum (Natural History).

Swinscow, T. D. V. (1989) Reap a Destiny London: British Medical Journal. [Autobiography].

Swinscow, Douglas (1992) The Mystic Garden Tiverton: Halsgrove Press.

\section{Medical Papers}

Swinscow, T. D. V. (1951) Some suicide statistics. British Medical Fournal 1951 (i): 1417-1423

Swinscow, 'T. D. V. (1951) So called accidental mechanical suffocation of infants. British Medical foumal 1951 (ii): 1004-1007.

Swinscow, T. D. V. (1953) Accidental poisoning of young children. Archives of Disease in Childhood 28: 26-29.

Bryological papers

Rose, F. \& Swinscow, T. D. V. (1956) Southbya nigrella (De Not.) in fruit. Transactions of the British Bryological Society 3: 124-125.

Swinscow, 'T. D. V. (1959) A bryophyte flora of Hertfordshire. Transactions of the British Bryological Society 3: 509-557.

Swinscow, T. D. V. (1959) Campylopus introflexus in fruit. Transactions of the British Bryological Society 3: 610 .

Swinscow, T. D. V. (1984) Tortula solmsii (Schimp.) Limpr. in south Devon. Fournal of Bryology 14: 131 .

General

Swinscow, T.D.V. (1972) Friedrich Welwitsch, 1806-72: A centennial memoir. Biological fournal of the Linnean Society 4: 269-289.

Lichenological papers

Editorial (unsigned). (1958) Lichenologist 1: 1-2.

Swinscow, T. D. V. (1953) An arctic-alpine lichen new to England. Lichenologist 1: 29-30.

Swinscow, T. D. V. (1960) Pyrenocarpous lichens: 1. Lichenologist 1: 169-178.

Swinscow, T. D. V. (1960) Cavernularia hultenii Degelius in Scotland. Lichenologist 1: 179-183.

Swinscow, T. D. V. (1961) Pyrenocarpous lichens: 2 Gongylia Körb. in the British Isles with first record of G.incarnata; Polyblastia verrucosa (Ach.) Lönnr. new to British Isles; Polyblastia terrestris Th. Fr. in the British Isles; Verrucaria psammophila Erichs. Lichenologist 1: 242-250.

Swinscow, T. D. V. (1962) Pyrenocarpous lichens: 3. The genus Porina in the British Isles. Lichenologist 2: 6-56.

Swinscow, T.D. V. (1962) An unusual parasymbiont of marine lichens. Nature 194: 500-501. 
Swinscow, T. D. V. (1963) Pyrenocarpous lichens: 4. Guide to the British species of Staurothele. Lichenologist 2: 152-166.

Swinscow, T. D. V. (1963) Pyrenocarpous lichens: Fruiting Normandina pulchella (Borr.) Nyl. A. cause of confusion; a further Porina species. Lichenologist 2: 167-171.

Swinscow T, D. V. (1964) Pyrenocarpous lichens: 6. The genus Thrombium in the British Isles. Species of Belonia Körb. in Britain. Lichenologist 2: 276-283.

Morgan-Jones, G., \& Swinscow, T. D. V. (1965) On the genus Microglaena Korb. Lichenologist 3: 42-54 (= Pyrenocarpous lichens 7)

Swinscow, T. D. V. (1964) The marine species of Arthopyrenia in the British Isles-Pyrenocarpous lichens: 8 . Lichenologist 3: 55-64.

Swinscow, T. D. V. (1965) Pyrenocarpous lichens: 9. Notes on various species. Lichenologist 3: $72-83$.

Swinscow, T. D. V. (1966) Pyrenocarpous lichens: 10. Lichenologist 3: 233-235.

Swinscow, T. D. V. (1966) The ascocarp of Anthracothecium pyrenuloides (Mont.) Müll. Arg. Lichenologist 3: 274-275.

Swinscow, T. D. V. (1966) Lichens with bitunicate asci. Nature 210: 852-853.

Swinscow, T. D. V. (1967) Pyrenocarpous lichens: 11. A new species of Arthopyrenia. Lichenologist 3: 415-417.

Swinscow, T. D. V. (1967) Pyrenocarpous lichens: 12. The genus Geisleria Nitschke. Lichenologist 3: $418-422$.

Swinscow, T. D. V. (1968) Pyrenocarpous lichens: 13. Fresh-water species of Verrucaria in the British Isles. Lichenologist 4: 34-54.

Swinscow, T. D. V. (1968) Tenth anniversary of the British Lichen Society. British Lichen Society Bulletin 22 (May): 1-2

Swinscow, T. D. V. (1970) Pyrenocarpous lichens: 14. Arthopyrenia Massal. sect. Acrocordia (Massal.) Müll. Arg. in the British Isles. Lichenologist 4: 218-233.

Topham, P. B. \& Swinscow, T. D. V. (1970) Thelenidia monosporella Nyl. In Greenland. Lichenologist 4: 294-296.

Swinscow, T. D. V. (1971) Pyrenocarpous lichens: 15. Key to Polyblastia Massal. in the British Isles. Lichenologist 5: $92-113$.

Krog, H. \& Swinscow, T. D. V. (1974) Ramalina species with a hollow thallus (Fistularia) in East Africa. Norwegian fournal of Botany 21: 111-124.

Swinscow, T. D. V. \& Krog, H. (1974) Usnea subgenus Eumitria in East Africa. Norwegian fournal of Botany 21: 165-185.

Swinscow, T. D. V. \& Krog, H. (1975) The genus Pyxine in East Africa. Norwegian fournal of Botany 22: 43-68.

Krog, H. \& Swinscow, T. D. V. (1975) Parmeliaceae, with the exclusion of Parmelia and Usnea, in East Africa. Norwegian fournal of Botany 22: 115-123.

Swinscow, T. D. V. \& Krog. H. (1975) Further observations on Pyxine in East Africa. Norwegian fournal of Botany 22: 125-128.

Krog, H. \& Swinscow, T. D. V. (1975) Variation in vegetative propagules in the African lichen Parmelia lophogena. Bryologist 78: 67-70.

Swinscow, T. D. V. \& Krog, H. (1975) The Usnea undulata aggregate in East Africa. Lichenologist 7: 121-138.

Swinscow, T. D. V. \& Krog, H. (1975) The genus Dermatocarpon in East Africa and an overlooked species in Britain. Lichenologist 7: 148-154.

Krog, H. \& Swinscow, T. D. V. (1975) The Ramalina species with punctiform pseudocyphellae in East Africa. Norwegian fournal of Botany 22: 269-276.

Swinscow, T. D. V. \& Krog, H. (1976) The Usnea bornmuelleri aggregate in East Africa. Norwegian fournal of Botany 23: 23-31.

Krog, H. \& Swinscow, T. D. V. (1976) The genus Ramalina in East Africa. Norwegian fournal of Botany 23: 153-175.

Swinscow, T. D. V. \& Krog, H. (1976) The genus Coccocarpia in East Africa. Norwegian fournal of Botany 23: 251-259.

Swinscow, T. D. V. \& Krog, H. (1976) The Usnea articulata aggregate in East Africa. Norwegian fournal of Botany 23: 261-268.

Swinscow, T. D. V. \& Krog, H. (1976) The genera Anaptychia and Heterodermia in East Africa. Lichenologist 8: 103-138.

Krog, H. \& Swinscow, T. D. V. (1977) The Parmelia borreri group in East Africa. Norwegian Fournal of Botany 24: 167-177. 
Swinscow, T. D. V. \& Krog, H. (1978) The genus Dirinaria in East Africa. Norwegian fournal of Botany 25: 157-168.

Swinscow, T. D. V. \& Krog, H. (1978) Pendulous species of Usnea in East Africa. Norwegian fournal of Botany 25: 221-241.

Krog, H. \& Swinscow, T. D. V. (1979) Parmelia subgenus Hypotrachyna in East Africa. Norwegian fournal of Botany 26: 11-43.

Swinscow, T. D. V. \& Krog, H. (1979) The lichen genera Heppia and Peltula in East Africa. Norwegian fournal of Botany 26: 213-224.

Swinscow, T. D. V. \& Krog, H. (1979) The fruticose species of Usnea subgenus Usnea in East Africa. Lichenologist 11:207-252.

Swinscow, T. D. V. (1980) Editorial (signed): The amateur in lichenology. International Lichenological Newsletter 13: 1-3.

Krog, H. \& Swinscow, T. D. V. (1981) Parmelia subgenus Amphigymnia (lichens) in East Africa. Bulletin, British Museum (Natural History), Botany 9: 143-231.

Swinscow, T. D. V. \& Krog, H. (1981) The genus Phyllopsora, with a report on East African species. Lichenologist 13: 203-247.

Krog, H. \& Swinscow, T. D. V. (1983) A new species and new combinations in Parmotrema (Parmeliaceae). Lichenologist 15: 127-130.

Swinscow, T. D. V. \& Krog, H. (1986) ['1985'] Phyllopsora longispora sp. nov. Nordic fournal of Botany 5: 493-495.

Krog, H. \& Swinscow, T. D. V. (1986) Solorina simensis and S. saccata. Lichenologist 18: 57-62.

Krog, H. \& Swinscow, T. D. V. The genera Lasallia and Umbilicaria in East Africa. Nordic fournal of Botany 6: 75-85.

Swinscow, T. D. V. \& Krog, H. (1986) A new species in the genus Collema from East Africa. Lichenologist 18: 63-70.

Swinscow, T. D. V. \& Krog, H. (1986) Some observations on the thallus in Pannaria with description of a new species. Lichenologist 18: 309-315.

Krog, H. \& Swinscow, T. D. V. (1986) Parmotrema hicksii Krog \& Swinscow sp. nov. Lichenologist 18: $292-293$.

Swinscow, T. D. V. \& Krog, H. (1986) Usnea antigua sp. nov. described from Tanzania. Lichenologist 18: 293-295.

Ahti, T., Krog, H. \& Swinscow, T. D. V. (1987) New or otherwise interesting Cladonia species in East Africa. Annales Botanici Fennici 24: 85-94.

Krog, H. \& Swinscow, T. D. V. (1987) New species and new combinations in some parmelioid lichen genera, with special emphasis on East African taxa. Lichenologist 19: 419-431.

Swinscow, T. D. V. (1991) Epilogue. In Tropical Lichens: Their Systematics, Conservation and Ecology (D. J. Galloway, ed.) Systematics Association Special Volume 43: 275-277. Oxford: Clarendon Press.

\section{Taxa introduced by Dougal Swinscow}

Arthopyrenia faginea (Schaerer) Swinscow

A. strontianensis Swinscow

Bacidia laciniosa Swinscow \& Krog

B. spruceana (Müll. Arg.) Swinscow \& Krog

Coccocarpia erythroxyli (Sprengel) Swinscow \& Krog

Collema laevisporum Swinscow \& Krog

Geislera jamesii Swinscow

Heterodermia albicans (Pers.) Swinscow \& Krog

$H$. antillarum (Vainio) Swinscow \& Krog

H. appendiculata (Kurok.) Swinscow \& Krog

$H$. chilensis (Kurok.) Swinscow \& Krog

H. congoensis (Kurok.) Swinscow \& Krog

$H$. dactyliza (Nyl.) Swinscow \& Krog

$H$. hypochraea (Vainio) Swinscow \& Krog

$H$. japonica (Sato) Swinscow \& Krog

H. lepidota Swinscow \& Krog

$H$. leucomelos ssp. boryi (Fée) Swinscow \& Krog
H. loroformis (Kurok.) Swinscow \& Krog H. magellanica (Zahlbr.) Swinscow \& Krog H. usambarensis (Kurok.) Swinscow \& Krog Hypotrachyna afrorevoluta (Krog \& Swinscow) Krog \& Swinscow

H. aurulenta (Tuck.) Krog \& Swinscow H. damaziana (Zahlbr.) Krog \& Swinscow H. horrescens (Taylor) Krog \& Swinscow H. minarum (Vainio) Krog \& Swinscow $H$. polydactyla (Krog \& Swinscow) Nash H. spathulata (Kurok) Krog \& Swinscow H. spumosa (Asah.) Krog \& Swinscow H. subfatiscens (Kurok.) Krog \& Swinscow H. swinscowii (Hale) Krog \& Swinscow Leptogium caespitosum (Taylor) Swinscow \& Krog

Pannaria santessonii Swinscow \& Krog

Parmotrema amaiense (Steiner) Krog \& Swinscow 
P. apricum (Krog \& Swinscow) Krog \& P.taylori (Carroll ex Nyl.) Swinscow Swinscow

P. consors (Nyl.) Krog \& Swinscow

$P$. degelianum Krog \& Swinscow

P. durumae (Krog \& Swinscow) Krog \& Swinscow

P. erubescens (Stirton) Krog \& Swinscow

$P$. glaucocarpoides (Zahlbr.) Krog \& Swinscow

$P$. hicksii Krog \& Swinscow

P. jacarandicola (Krog \& Swinscow) Krog \& Swinscow

P. leonis (Krog \& Swinscow) Krog \& Swinscow

P. pardi (Krog \& Swinscow) Krog \& Swinscow

$P$. pigmentiferum (Krog \& Swinscow) Krog \& Swinscow

P. pilosum (Stizenb.) Krog \& Swinscow

$P$. poolit (Dodge) Krog \& Swinscow

$P$. ravum (Krog \& Swinscow) Sérus.

$P$. stuhlmanni (Dodge) Krog \& Swinscow

P. taitae (Krog \& Swinscow) Krog \& Swinscow

P. tsavoense (Krog \& Swinscow) Krog \& Swinscow

P. umbrosum (Krog \& Swinscow) Krog \& Swinscow

P. vividum (Krog \& Swinscow) Krog \& Swinscow

Peltula africana (Jatta) Swinscow \& Krog

$P$. congregata (Nyl.) Swinscow \& Krog

$P$. impressa (Vainio) Swinscow \& Krog

$P$. lingulata (Vainio) Swinscow \& Krog

$P$. patellata (Bagl.) Swinscow \& Krog

$P$. santessonit Swinscow \& Krog

P. umbilicata (Vainio) Swinscow \& Krog

Phyllopsora bibula (Taylor) Swinscow \& Krog

$P$. confusa Swinscow \& Krog

P. glabriuscula (Nyl.) Swinscow \& Krog

$P$. janeirensis (Müll. Arg) Swinscow \& Krog

$P$. longispora Swinscow \& Krog

$P$. martinii Swinscow \& Krog

P. mediocris Swinscow \& Krog

P. microphyllina (Tuck. ex Nyl.) Swinscow \& Krog

P. pertexta (Nyl.) Swinscow \& Krog

P. pyrrhomelaena (Tuck.) Swinscow \& Krog

P. santensis (Tuck.) Swinscow \& Krog

Porina chlorotica f. tenuifera (Ny1.) Swinscow

$P$. guentheri var. grandis (Körb.) Swinscow

P. guentheri var. curnowii (A.L.Sm.) Swinscow

$P$.guentheri var. lucens (Taylor) Swinscow

$P$. hibernica P. James \& Swinscow

P. septemseptata (Hepp ex Zwackh) Swinscow

Pseudoparmelia chlorea (Stizenb.) Krog \& Swinscow

P. endochromatica Krog \& Swinscow

P. simplicior (Hale) Krog \& Swinscow

$P$. singularis $\mathrm{K}$ rog $\&$ Swinscow

P. usambarensis (Steiner \& Zahlbr.) Krog \& Swinscow

$P$. wallichiana (Taylor) Krog \& Swinscow

Pyxine convexior (Müll. Arg.) Swinscow \& Krog

$P$. katendei Swinscow \& Krog

$P$. kibweziensis Swinscow \& Krog

P. lilacina Swinscow \& Krog

P. lyei Swinscow \& Krog

P. maculata Swinscow \& Krog

P. petricola var. pallida Swinscow \& Krog

$P$. vermiformis Swinscow \& Krog

Ramalina calcarata Krog \& Swinscow

$R$. celastri (Sprengel) Krog \& Swinscow

$R$. disparata Krog \& Swinscow

R. fecunda Krog \& Swinscow

R. fimbriata Krog \& Swinscow

R. holstii Krog \& Swinscow

$R$. maritima Krog \& Swinscow

$R$. pentecostii Krog \& Swinscow

$R$, pocsii Krog \& Swinscow

$R$. reducta Krog \& Swinscow

$R$. sprengelii Krog \& Swinscow

R. subpusilla (Nyl.) Krog \& Swinscow

R. tapperi Krog \& Swinscow

$R$, translucida Krog \& Swinscow

Stricta sublimbata (Steiner) Swinscow \& Krog

Stigmidium marinum (Deak.) Swinscow \& Krog

Umbilicaria africana (Jatta) Krog \& Swinscow

$U$. soralifera (Frey) Krog \& Swinscow

$U$. umbilicarioides (B. Stein) Krog \& Swinscow

Usnea antiqua Swinscow \& Krog

$U$. baileyi var. pinnatifida Swinscow \& Krog

$U$. baileyi var. planiiscula Swinscow \& $\mathrm{Krog}$

$U$.goniodes (Stirton) Swinscow \& Krog

$U$. nodulosa Swinscow \& Krog

$U$. sanguinea Swinscow \& $\mathrm{Krog}$

U. subeciliata (Mot.) Swinscow \& Krog

Xanthoparmelia glomerulata $\mathrm{K} r o g \&$ Swinscow

$X$. interrupta (Stizenb.) Krog \& Swinscow

$X$. karamojae Krog \& Swinscow

$X$. kiboensis (Dodge) Krog \& Swinscow

$X$. meruensis Krog \& Swinscow

\section{Three species have been named after Dougal Swinscow.}

Dermatina swinscowii Riedl, in Sydowia (1964) 17: 104; since reduced to synonymy with Arthothelium lirellans (Almq.) Coppins, in Lichenologist (1979) 11: 28.

Parmelia swinscowit Hale, in Phytologia (1973) 27:4.

Polyblastiopsis swinscowii Riedl, in Lichenologist (1979) 11: 47.

Peter W. James 